\title{
Morphological and molecular analyses of parasitic barnacles (Crustacea: Cirripedia: Rhizocephala) in Korea: Preliminary data for the taxonomy and host ranges of Korean species
}

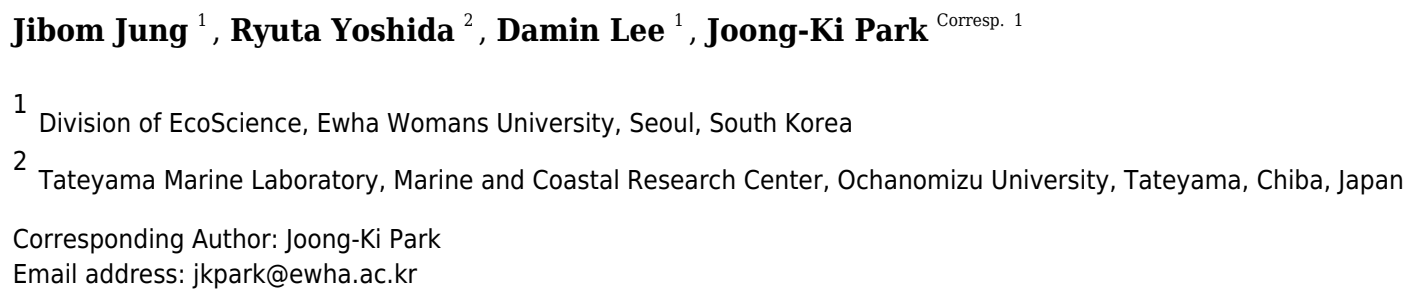

Morphological and molecular analyses of Korean rhizocephalan barnacle species were performed to examine their host ranges and taxonomy. Morphological examination and molecular analysis of mtDNA cox1, 16S, and nuclear 18S rRNA sequences revealed nine rhizocephalan species from three genera of the two families, Sacculinidae and Polyascidae. Phylogenetic analysis of molecular sequences revealed two new species candidates in the genus Parasacculina, and three Sacculina species (S. pilosella, S. pinnotherae, and S. imberbis) were transferred to the genus Parasacculina. Examination of host ranges revealed higher host specificity and lower infestation rates in Korean rhizocephalan species than rhizocephalans from other geographic regions. This is the first report of the taxonomy, species diversity, and host ranges of Korean parasitic rhizocephalan barnacles based on their morphological and molecular analyses. More information from extensive sampling of parasitic barnacles from a wide range of crustacean host species is necessary to fully understand their taxonomy, prevalence on decapod hosts, and phylogenetic relationships among major rhizocephalan taxa. 


\section{Morphological and molecular analyses of parasitic barnacles}

2 (Crustacea: Cirripedia: Rhizocephala) in Korea: Preliminary data

3 for the taxonomy and host ranges of Korean species

4 Jibom Jung ${ }^{1}$, Ryuta Yoshida ${ }^{2}$, Damin Lee ${ }^{1}$, Joong-ki Park ${ }^{1}$

$5 \quad{ }^{1}$ Division of EcoScience, Ewha Womans University, Seoul, South Korea

62 Tateyama Marine Laboratory, Marine and Coastal Research Center, Ochanomizu University, Kou-yatsu,

7 Tateyama, Chiba, Japan

8

9 Corresponding Author:

10 Joong-ki Park ${ }^{1}$

11 Division of EcoScience, Ewha Womans University, Seoul, 03760, South Korea

12 Email address: jkpark@ewha.ac.kr 


\section{Abstract:}

15 Morphological and molecular analyses of Korean rhizocephalan barnacle species were performed

16 to examine their host ranges and taxonomy. Morphological examination and molecular analysis of

17 mtDNA cox $1,16 \mathrm{~S}$, and nuclear $18 \mathrm{~S}$ rRNA sequences revealed nine rhizocephalan species from

18 three genera of the two families, Sacculinidae and Polyascidae. Phylogenetic analysis of molecular

19 sequences revealed two new species candidates in the genus Parasacculina, and three Sacculina species (S. pilosella, S. pinnotherae, and S. imberbis) were transferred to the genus Parasacculina.

21 Examination of host ranges revealed higher host specificity and lower infestation rates in Korean rhizocephalan species than rhizocephalans from other geographic regions. This is the first report of the taxonomy, species diversity, and host ranges of Korean parasitic rhizocephalan barnacles based on their morphological and molecular analyses. More information from extensive samplings of parasitic barnacles from a wide range of crustacean host species is necessary to fully understand their taxonomy, prevalence on decapod hosts, and phylogenetic relationships among major rhizocephalan taxa.

\section{Introduction}

The Rhizocephala comprises morphologically highly modified parasitic barnacles that use a wide range of crustacea as their hosts, mostly parasites on decapods. Members of this group have complex life cycles, usually involving a series of pelagic larval stages followed by an endoparasitic interna stage and a reproductive externa stage where many organ systems (e.g., respiratory, digestive, sensory, and excretory systems) degenerate (Høeg, 1992; Øksnebjerg, 2000). In contrast to other crustacean species, they have a very simplified external structure (externa) and lack 
36

37

segmentation and appendages in the parasitic stage (Høeg \& Lützen, 1995). Due to the simplified morphology of the externa, previous taxonomic studies of rhizocephalans have been based largely on larval morphology and the fine structure of externa observed from paraffin sectioning (Yoshida et al., 2011; Kobayashi et al., 2018), with further validation through DNA barcoding analysis (Yoshida et al., 2012; 2014; Høeg et al., 2019; Jung et al., 2019). Very recently, Høeg et al. (2019) modified the taxonomic system of Rhizocephala based on molecular phylogenetic analysis of $18 \mathrm{~S}$ rDNA sequences, and the latest molecular-based taxonomy of rhizocephalan barnacles was included in Chan et al. (2021).

Since the first report of rhizocephalan barnacles (Krüger, 1912; Høeg \& Lützen, 1985), northwestern Pacific species have been reported from southeast Russia (Korn et al., 2020), China (Tu et al., 2009), Taiwan (Yoshida et al., 2012), Japan (Shiino, 1943; Utinomi \& Kikuchi, 1966; Nagasawa et al., 1996), and Korea (Jung et al., 2019). Although Jung et al. (2019) described 10 species of peltogastrid barnacles from 17 hermit crab species in Korea, little is known about the species diversity, distribution, taxonomy, and host range of other rhizocephalan parasitic barnacles in Korea. In this study, we characterized nine rhizocephalan species, including two new cryptic species candidates, based on morphological examination and molecular analyses of mitochondrial (cytochrome c oxidase subunit I and 16S) and nuclear 18S rDNA sequences. In addition to the taxonomic accounts of the Korean species, we also investigated the prevalence of parasitic barnacles in decapod hosts and phylogenetic relationships among rhizocephalan species.

\section{Methods}


57 We examined the abdomens of 3,262 individuals of 25 Korean decapod host species collected 58 from 16 sampling sites in Korea. In addition, 12 Japanese rhizocephalans from 11 sampling sites 59 were obtained for comparative molecular study (Tables 1, 2). Korean voucher specimens in this 60 study were deposited in the National Institute of Biological Resources (NIBR) and Honam the 61 National Institute of Biological Resources (HNIBR). Japanese voucher specimens in this study 62 were deposited in the Ryukyu University Museum, Fujukan, University of the Ryukyus, Okinawa, 63 Japan (RUMF), and Coastal Beach of Natural History Museum and Institute, Chiba, Japan $64(\mathrm{CMNH})$.

All rhizocephalan specimens were fixed in $95 \%$ ethanol and subjected to morphological examination and molecular analysis. For morphological analysis, the externa and mantle were examined using an MZ8 dissection microscope (Leica, Wetzlar, Germany). Photographs were taken with a D200 digital camera (Nikon, Tokyo, Japan). Carapace length (cl) of the host decapod was measured as the length from the tip of the rostrum to the midpoint of the posterior margin of the carapace using a CD6CSX digital caliper (Mitutoyo, Kawasaki, Japan) to the nearest $0.1 \mathrm{~mm}$. For molecular analysis, the lateral end of the externa tissue of each rhizocephalan specimen was excised for total genomic DNA extraction using the QIAamp DNA Micro Kit (QIAGEN, Hilden, Germany). Universal primers LCO1490 (5'-GGTCAACAAATCATAAAGATATTGG-3') and HCO2198 (5'-TAAACTTCAGGGTGACCAAAAAATCA-3') were used to amplify a fragment of mitochondrial cytochrome c oxidase subunit I (coxl) (Folmer et al., 1994). To amplify the mitochondrial 16S rDNA gene, 16SH2 (5'-AGATAGAAACCAACCTGG-3') and 16SL2 (5'TGCCTGTTTATCAAAAACAT-3') primers (Schubart et al., 2000) were used. For PCR amplification of $18 \mathrm{~S}$ rDNA, 18S-329R (TAATGATCCTTCCGCAGGTT) and 18S-AF (CAGCMGCCGCGGTAATWC) primers were used (Spears et al., 1992). Polymerase chain 
reaction (PCR) was performed in reaction volumes of $50 \mu \mathrm{L}$ that included $2 \mu \mathrm{L}$ DNA template, 5 $\mu \mathrm{L} 10 \mathrm{x}$ Ex Taq Buffer, $2 \mu \mathrm{L}$ of each primer $(10 \mu \mathrm{M}), 0.25 \mu \mathrm{L}$ Go Taq DNA polymerase (Promega, Madison City, WI, USA), $2.5 \mu \mathrm{L}$ dNTP mix $(10 \mathrm{mM})$, and $35.75 \mu \mathrm{L}$ distilled $\mathrm{H}_{2} \mathrm{O}$. PCR amplification was performed using the following steps: 5 min denaturation at $94^{\circ} \mathrm{C}$ followed by 35 cycles of $30 \mathrm{sec}$ at $94^{\circ} \mathrm{C}, 1 \mathrm{~min}$ at $52^{\circ} \mathrm{C}, 1 \mathrm{~min}$ at $72^{\circ} \mathrm{C}$, and a final extension of 7 min at $72^{\circ} \mathrm{C}$. PCR products were visualized on 1\% agarose gels and sequenced with an ABI PRISM 3730xl DNA analyzer (Applied Biosystems, Foster City, CA, USA). Nucleotide sequences of the three gene fragments (mtDNA coxl, 16S, and nuclear 18S rDNA) were analyzed and edited using Geneious v. 9.1.8 (Kearse et al., 2012) and aligned using ClustalW in the MEGA10 program (Kumar et al., 2018). Nucleotide sequences were deposited in GenBank (mtDNA coxl: MZ216468- MZ216513; 16S: MZ215675- MZ215720; 18S rDNA: MZ215557- MZ215602). Forty-six additional rhizocephalan sequences of Sacculinidae and Polyascidae species available in GenBank were downloaded and included in the phylogenetic analyses (Table 2).

Phylogenetic relationships among rhizocephalan species were inferred for each of the three genes using maximum likelihood (ML) analysis and Bayesian inference (BI) implemented in RaxML version 8 (Stamatakis, 2014) and MrBayes v3.2.6 (Ronquist et al., 2011), respectively. Phylogenetic trees were modified by MEGA 10. Maximum likelihood analyses of coxl, 16S, and 18S rDNA sequences were performed based on the Tamura-Nei (TN93) (Tamura \& Nei, 1993), general time reversible (Tavaré, 1986), and Kimura 2-parameter (Kimura, 1980) models, respectively, with a gamma distribution $(+\mathrm{G})$ and invariable sites $(+\mathrm{I})$ rate categories based on Bayesian Information Criterion (BIC) scores model using the Model Selection option of MEGA10. The robustness of individual nodes in the ML trees was assessed by analysis of 1,000 bootstrap 
102 replications. Interspecific and intraspecific sequence divergences were estimated based on the K2P 103 distance matrix in MEGA10.

104

105

\section{Results}

106

Based on morphological examination (shape and number of externae and mantle aperture) and mitochondrial sequence information, we identified 38 rhizocephalan individuals belonging to nine species, three genera, and two families isolated from eight decapod hosts species collected from 16 sites (Fig. 1; Table 2). All rhizocephalans identified by this study except Parasacculina

pinnotherae comb. nov. were first reported from Korea. Detailed information regarding the Korean rhizocephalan species and their externa morphology is provided in Table 3.

\section{Taxonomic accounts and morphological features of Korean rhizocephalan species}

114 Sacculinidae Lilljeborg, 1861

115 Sacculina Thompson, 1836

\section{Sacculina confragosa Boschma, 1933 (Fig. 2A)}

117 Materials examined: on Gaetice depressus: 1 ind., Sacheon (34.9 N 128.1 E), Korea 5, host:, , cl

$11811.5 \mathrm{~mm}$; 1 ind. (2 externa), Sacheon (34.9 N 128.1 E), Korea 6, host: $q$, cl 11.8 mm; 1 ind.,

119 Sacheon (34.9 N 128.0 E), Korea 7, host: ㅇ, cl 13.7 mm; 1 ind., Sacheon (34.9 N 128.0 E), Korea 120 8, host: + , cl 9.1 mm; 1 ind., Sacheon (34.9 N 128.1 E), Korea 9, host: $\circ$, cl 10.3 mm; 1 ind., 121 Sacheon (34.9 N 128.1 E), Korea 10, host: + , cl 11.8 mm; 1 ind., Namhae (34.7 N 127.9 E), Korea 122 11, host: đ̂, cl $11.9 \mathrm{~mm}$, feminization; 1 ind. (2 externa), Namhae (34.7 N 127.9 E), 
123 VSJAIV0000000015, Korea 12, host: + , cl 7.7 mm; 1 ind., Yeosu (34.7 N 127.8 E), Korea 13,

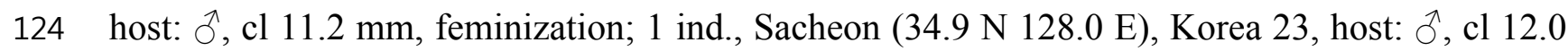

125 mm; 1 ind., Sacheon (34.9 N 128.0 E), Korea 24, host: đ̊, cl 13.9 mm; 1 ind., Tongyeong (34.8 N

126 128.4 E), VSJAIV0000000016, Korea 33, host: +, cl 7.1 mm; 1 ind., Tongyeong (34.8 N 128.4

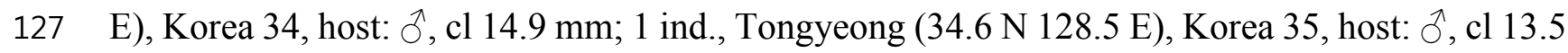
$128 \mathrm{~mm}$.

129 Host species: G. depressus, Pachygrapsus crassipes (Grapsidae), Cyclograpsus intermedius 130 (Varunidae).

131 Distribution: Japan, Korea.

132 Diagnosis of the externa: whole externa mostly single and occasionally double, wrinkled cordiform 133 with flat half-oval-shaped left and right lobes divided by an outer mid-groove and inner mid-ridge; 134 outermost part of the robe wrinkled. Mantle well elevated, tube-shaped, and vertically slightly 135 wrinkled with a circular opening at the extremity.

136 Remarks: Morphological characteristics of the examined materials correspond with their original 137 description (Boschma, 1933) except for the number of externa. Some of our specimens (Korea 6, 138 Korea 12) had double externae (15\% of total examined individuals), whereas others had a single 139 externa. This type of variation in the number of externa has been reported in a previous study 140 (Shiino, 1943). This species is found most abundantly parasitizing medium-sized individuals of 141 host crab species. Further study is needed to determine if this species is a predominant parasitic 142 form on medium-sized host individuals. 
145 Polyascidae Høeg \& Glenner in Høeg, Noever, Rees, Crandall \& Glenner, 2019

146 Parasacculina Høeg \& Glenner in Høeg, Noever, Rees, Crandall \& Glenner, 2019

147 Materials examined: 1 ind., Namhae (34.7 N 128.0 E), Korea 4, host: $\uparrow$, cl 12.5 mm.

148 Host species: Pachygrapsus crassipes (Grapsidae).

149 Distribution: Japan, Korea.

150 Diagnosis of the externa: whole externa smooth, single, with a rounded-rectangular shape.

151 Remarks: The examined specimen had a single externa, but we were not able to examine 152 morphological characteristics in more detail due to the immature stage of the specimen. Species 153 identification of this specimen and its taxonomic placement in the genus Parasacculina were based 154 on molecular analyses of mtDNA $\operatorname{cox} 1,16 \mathrm{~S}$, and nuclear $18 \mathrm{~S}$ gene sequences (Fig. 3A-3C; see 155 Discussion for more details).

Parasacculina pilosella (Van Kampen \& Boschma, 1925) comb. nov. (Fig. 2B)

158 Material examined: 1 ind., Sacheon (34.9 N 128.1 E), VSJAIV0000000010, Korea 3, host: $\widehat{\jmath}$, cl $159 \quad 13.7 \mathrm{~mm}$.

160 Host species: Pugettia intermedia (Epialtidae).

161 Distribution: Indonesia, Japan, Korea.

162 Diagnosis of the externa: whole externa smooth, single, and slightly flat and oval. Mantle flat and 163 vertically slightly wrinkled with a circular opening at the extremity. 
164 Remarks: Four Sacculina species (S. muricata Boschma, 1931, S. pugettiae Shiino, 1943, S. 165 reinhardi Boschma, 1955, and S. pilosella) were previously reported to parasitize Pugettia spp.. 166 Morphological characteristics of the examined specimen correspond with the original description 167 of S. pillosella (Van Kampen \& Boschma, 1925). However, phylogenetic analysis of mtDNA 16S 168 and 18S rDNA sequences showed that this species is nested within Parasacculina species (Fig. 169 3B and 3C), separated from Sacculina species (S. confragosa, S. upogebiae, and S. carcini). 170 Therefore, we consider this species a member of the genus Parasacculina (see Discussion for more 171 details).

Parasacculina pinnotherae (Shiino, 1943) comb. nov. (Fig. 2C)

174

175

176

177

178

179

180

181

182

183

Materials examined: 1 ind., Busan (35.2 N 129.2 E), Korea 1, host: $q$, cl 9.1 mm, in the mussel; 1 ind. (2 externa), Busan (35.2 N 129.2 E), Korea 2, host: §̊, cl 6.9 mm, in the mussel.

Host species: Arcotheres sinensis (Pinnotheridae).

Distribution: Japan, Korea.

Diagnosis of the externa: whole externa smooth or slightly wrinkled, single or double, and flat oval or cordiform in shape; each outer-posterior margin elevated into a conical shape. Mantle slightly elevated and vertically wrinkled with a small round opening at the extremity.

Remarks: Two Sacculina species (S. pertenuis Boschma, 1933 and S. pinnotherae) have been reported to be parasitic on Pinnotheres spp.. Morphological characters of examined specimens correspond with the original description of S. pinnotherae (Shiino, 1943). 
184 However, phylogenetic analysis of mtDNA cox $1,16 \mathrm{~S}$, and nuclear 18S rDNA sequences placed 185 this species within the genus Parasacculina (Fig. 3A-3C), not in the genus Sacculina. Therefore, 186 we treated this species as a member of the genus Parasacculina (see Discussion for more details).

187 The host crab (Arcotheres sinensis) is known to parasitize bivalves, so $P$. pinnotherae comb. nov. 188 is a secondary parasite that is rare in the ocean (McDermott, 2009).

\section{Parasacculina shiinoi (Lützen, Itani, Jespersen, Hong, Rees \& Glenner, 2016)}

Materials examined: 1 ind., Namhae (34.9 N 127.9 E), Korea 25, host: cl 8.8 mm; 1 ind., Namhae (34.9 N 127.8 E), Korea 26, host: cl $11.1 \mathrm{~mm}$.

Host species: Upogebia major (Upogebiidae).

Distribution: Japan, Korea.

Diagnosis of the externa: whole externa smooth, single, oval in shape.

Remarks: The examined specimens had a single externa, but detailed morphological characteristics could not be determined because of the immaturity of the specimens examined. Lützen et al. (2016) reported that Sacculina upogebiae parasitizes Upogebia species. Molecular analysis of mtDNA 16S rDNA sequences revealed that this species grouped with $P$. shiinoi (GenBank accession no: KF539761: Fig. 3B) with very high sequence identity (98.9\%). (34.9 N 128.0 E), Korea 15, host: + , cl 8.0 mm; 1 ind., Sacheon (34.9 N 128.0 E), Korea 16, host: 
205 ふै, cl 9.7 mm; 1 ind., Sacheon (34.9 N 128.0 E), Korea 17, host: §̊, cl 9.9 mm; 1 ind., Yeosu (34.7

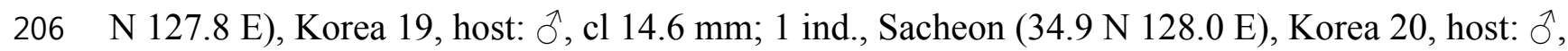

207 cl 14.1 mm; 1 ind., Sacheon (34.9 N 128.0 E), Korea 21, host: §̊, cl 17.7 mm.

208 Host species: Macromedaeus distinguendus (Xanthidae).

209 Distribution: Korea.

210 Diagnosis of the externa: whole externa single, smooth or slightly wrinkled, and oval in shape.

211 Mantle large, elevated, and vertically wrinkled with circular opening at the extremity.

212 Remarks: Parasacculina leptodiae and P. sinensis have been reported to be parasites of Leptodius

213 affinis, the most phylogenetically similar host species to $M$. distinguendus among the currently

214 known hosts of Rhizocephala. However, the specimens examined in this study differ in 215 morphology and molecular sequences from $P$. leptodiae and $P$. sinensis. This species has a single

216 externa, whereas $P$. leptodiae has multiple externae. In addition, this species has a large, elevated

217 mantle aperture, but $P$. leptodiae and $P$. sinensis have a flat mantle (Guérin-Ganivet, 1911;

218 Boschma, 1933). Phylogenetic analysis clearly showed that the cox1, 16S, and 18S rDNA

219 sequences of this species are different from those of $P$. leptodiae and $P$. sinensis and all other

220 Parasacculina species included in the analyses (Fig. 3A-C). Therefore, we considered this species

221 to be a new species candidate of the genus Parasacculina (see Discussion for more details).

223 Parasacculina sp. 2 (Fig. 2E)

224 Material examined: 1 ind., Sacheon (34.9 N 128.1 E), Korea 18, host: $\widehat{\jmath}$, cl 13.5 mm.

225 Host species: Macromedaeus distinguendus (Xanthidae). 
Distribution: Korea.

227 Diagnosis of the externa: whole externa smooth, single, and oval in shape. Mantle slightly elevated 228 with circular opening at extremity.

229 Remarks: Previously, P. leptodiae and P. sinensis were known to be parasites of L. affinis, the 230 most phylogeneically similar host species to $M$. distinguendus among the currently known hosts 231 of Rhizocephala. However, the examined specimen of this species differed in morphology and 232 molecular sequence from all Parasacculina species including Parasacculina sp. 1. This species 233 has one externa compared to the multiple externae of $P$. leptodiae. In addition, this species has a 234 slightly elevated mantle aperture, whereas $P$. leptodiae and $P$. sinensis have a flat mantle (Guérin235 Ganivet, 1911; Boschma, 1933), and Parasacculina sp. 1 has a well-elevated mantle. Furthermore, 236 phylogenetic analysis of mtDNA cox $1,16 \mathrm{~S}$, and nuclear $18 \mathrm{~S}$ rDNA sequences distinguished this 237 species from other Parasacculina species with 18.1-30.6\% sequence divergence in cox $1,14.0$ $23827.5 \%$ sequence divergence in 16S rDNA, and 1.9-4.2\% sequence divergence in 18S rDNA (Fig. $2393 \mathrm{~A}-\mathrm{C})$. Therefore, we treated this species as a new species candidate of the genus Parasacculina 240 (see Discussion for more details).

\section{Parasacculina yatsui (Boschma, 1936) (Fig. 2F)}

243 Materials examined: on Hemigrapsus sanguineus: 1 ind., Yeosu (34.1 N 127.3 E), 244 VSJAIV0000000011, Korea 36, host: + , cl 22.3 mm; 1 ind., Tongyeong (34.8 N 128.4 E), Korea

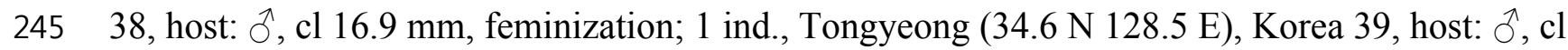
$24614.2 \mathrm{~mm}$, feminization.

247 Host species: Pachygrapsus crassipes (Grapsidae), H. sanguineus (Varunidae). 
Distribution: Japan, Korea.

249

250

251

252

253

254

255

256

257

258

259

260

261

262

263

264

265

266

267

268

Diagnosis of the externa: whole externa smooth or slightly wrinkled, single, and cordiform with flat half-oval-shaped left and right lobes divided by outer mid-groove and inner mid-ridge; outermost part of the robe wrinkled. Mantle tube-shaped, elevated, and slightly wrinkled with slit opening at extremity.

\section{Polyascus cf. gregarius (Okada \& Miyashita, 1935) (Fig. 2G)}

Polyascus Glenner, Lützen \& Takahashi, 2003

Materials examined: on H. sanguineus: 1 ind., Namhae (34.7 N 127.9 E), VSJAIV0000000013, Korea 27, host: + , cl 18.4 mm; 1 ind., Yeosu (34.7 N 127.8 E), VSJAIV0000000014, Korea 28, host: ${ }^{\lambda}$, cl 29.8 mm, feminization; 1 ind., Sacheon (34.9 N 128.1 E), Korea 29, host: + , cl 9.8 mm; 1 ind., Namhae (34.9 N 127.8 E), Korea 30, host: ${ }_{0}$, cl 16.7 mm, feminization; 1 ind., Yeosu (34.7 N 127.8 E), Korea 31, host: Ô, cl 8.9 mm, feminization; 1 ind., Taean (36.8 N $126.1 \mathrm{E})$, VSJAIV0000000012, Korea 37, host: đ̊, cl $14.1 \mathrm{~mm}$, feminization.

on H. takanoi: 1 ind., Namhae (34.9 N 127.9 E), Korea 32, host: $\widehat{\alpha}$, cl 9.5 mm.

Host species: Hemigrapsus sanguineus, H. takanoi, Eriocheir japonica (Varunidae).

Distribution: Japan, Korea.

Diagnosis of the externa: whole externa smooth or slightly wrinkled, single, and flat-cordiform shaped with flat half-oval-shaped left and right lobes divided by an outer mid-groove and inner mid-ridge; outermost part of the robe smooth or slightly wrinkled. Mantle tube-shaped, elevated, and vertically wrinkled with slit-shaped opening at the extremity. 
269 Remarks: Morphological characteristics of the examined materials correspond with their original

270 description (Okada \& Miyashita, 1935) except for the number of externa and the host species. All

271 specimens examined in this study had a single externa, whereas $P$. gregarius has multiple externae.

272 In addition, the host species (H. sanguineus and H. takanoi) differ from the host species reported

273 for $P$. gregarius, namely E. sinensis. Nevertheless, this species is likely $P$. gregarius because $18 \mathrm{~S}$

274 rDNA sequences of these specimens were identical to the GenBank sequences of P. gregarius

275 (Fig. 3C). In addition, individual variation in the number of externa of rhizocephalans has also

276 been reported previously (Reinhard, 1942; Shiino, 1943; Høeg \& Lützen, 1985).

277 In phylogenetic trees (Fig. 3A-3C), Polyascus cf. gregarious was clustered with P. planus that is 278 commonly found in Japan and Taiwan. These two species are similar in having a flat-cordiform 279 shaped externa, but different in some aspects of morphology and host species: the former has an 280 elevated mantle and single externa, while the latter has an underdeveloped mantle and multiple 281 externae (Boschma, 1933). In addition, the Grapsidae crabs (Grapsus albolineatus and 282 Metopograpsus messor) are known as P. planus host (Tu et al., 2009), whereas H. sanguineus and 283 H. takanoi belonging to the Varunidae are used as $P$. cf. gregarious hosts. Morphological and host 284 range variation among rhizocephalan species has been reported by previous studies (Høeg \& 285 Lützen, 1985; Jung et al., 2019), and thus further studies with broader taxon sampling of $P$. 286 gregarious and $P$. planus are needed to confirm an accurate species delimitation in their 287 morphology and host range. 
290 Since only Sacculinidae and Polyascidae species were found in this study, we focused on

291 phylogenetic relationships among rhizocephalan species in these two families. Totals of 34 cox 1

292 (555 bp), 33 16S rDNA (474 bp), and 35 18S rDNA (1002 bp) sequences were used for 293 phylogenetic analysis, and the resulting ML and Bayesian trees were consistent with each other in 294 that Sacculinidae and Polyascidae were monophyletic (Fig. 3A-3C). In all phylogenetic trees, the 295 sequences of Korean rhizocephalans species nested and/or clustered with sequences of the same 296 species retrieved from GenBank (Fig. 3A-3C).

297 Parasacculina sp. 1 and 2 were recognized as new species candidates because they did not show 298 sister relationships with other Parasacculina species (Fig. 3A-3C). In the 16S and 18S DNA trees, 299 they were placed at different positions and separated from $P$. leptodiae and $P$. sinensis, which share 300 the host family and have similar morphological characteristics (Fig. 3B and 3C). Parasacculina 301 sp. 1 and Parasacculina sp. 2 formed a group with P. shiinoi, but their 16S pairwise sequence 302 divergences from $P$. shiinoi were substantial, ranging from 18.2-20.9\% for Parasacculina sp. 1 and 14.4-14.8\% for Parasacculina sp. 2. This group (Parasacculina sp. 1, Parasacculina sp. 2, and $P$. shiinoi) was separate from $P$. leptodiae in the $16 \mathrm{~S}$ tree, whereas it was basal to the remaining Polyascidae species, including $P$. leptodiae and $P$. sinensis, in the $18 \mathrm{~S}$ tree. In the cox 1 tree, Parasacculina sp. 1 formed a well-defined sister group to Polyascus species (P. cf. gregarious and 307 P.planus), whereas Parasacculina sp. 2 was grouped with the Korean isolate of $P$. shiinoi showing 18.1\% sequence divergence (Fig. 3A). Interspecific sequence differences of the two new species candidates from other Polyascidae species were $18.1-32.1 \%$ for cox $1,14.0-28.8 \%$ for $16 \mathrm{~S}$ rDNA, and $1.9-4.7 \%$ for $18 \mathrm{~S}$ rDNA. In contrast to the high interspecific sequence divergences discovered, there were no individual variations in cox $1,16 \mathrm{~S}$, and $18 \mathrm{~S}$ rDNA sequences among Parasacculina 312 sp. 1 specimens. 
313 The three Sacculina species (S. imberbis, S. pilosella, and $S$. pinnotherae) clustered with

314 Parasacculina species (Fig. 3A-3C): S. imberbis grouped with S. pinnotherae, that is sister to other

315 Parasacculina species based on analysis of coxl (P. yatsui, P. granifera) and 18S rDNA (P. yatsui,

316 P. sinensis, $P$. leptodiae) sequences (Fig. 3A, 3C). S. pilosella formed a sister group to $P$.

317 compressa, P. oblonga, and $P$. yatsui in the $16 \mathrm{~S}$ and $18 \mathrm{~S}$ rDNA trees (Fig. 3B and 3C).

318 Interspecific sequence differences between Sacculina species and Parasacculina species were 319 remarkably large, ranging from $27.3-33.4 \%$ for cox $1,27.5-34.9 \%$ for $16 \mathrm{~S}$ rDNA, and $9.2-10.1 \%$

320 for $18 \mathrm{~S}$ rDNA. In contrast, intraspecific sequence divergences were very low with a maximum

321 sequence difference of $1.0 \%$ for cox 1 and $0.2 \%$ sequence difference for $16 \mathrm{~S}$ rDNA sequences

322 among $S$. confragosa individuals. All S. pinnotherae individuals had identical coxl, 16S, and $18 \mathrm{~S}$

323 rDNA sequences (Fig. 3A-3C).

\section{Discussion}

326 In this study, we identified nine species of Korean rhizocephalans from eight host decapod species using morphological and molecular analyses. Close examination of host ranges revealed that Korean rhizocephalan species have a different host prevalence than reported for rhizocephalan species from other geographic regions. In Korea, rhizocephalans were firstly found from three decapod hosts, i.e., Hemigrapsus takanoi, Macromedaeus distinguendus, and Pugettia intermedia. We also found that most Korean rhizocephalans showed high host specificity, parasitizing only one host, except Polyascus cf. gregarius that was found on two crab species. The notable differences in host range between geographic isolates (i.e. rhizocephalans from Korea and other geographic regions) might be due to geographical variation in host species diversity and abundance or insufficient information about the geographic origins of host crab species as proposed by Jung 
336 et al. (2019). In addition, unlike Korean S. confragosa individuals that were all found on only one

337 grapsid crab species, Gaetice depressus, the Japanese form is known to parasitize three crab

338 species, G. depressus, Pachygrapsus crassipes, and Cyclograpsus intermedius. Furthermore,

339 Japanese P. yatsui parasitizes not only G. depressus, but also P. crassipes (Tsuchida et al., 2006;

340 Kobayashi et al., 2018), whereas the Korean form of P. yatsui was found only on Hemigrapsus

341 sanguineus. We could not determine if other crab species including P. crassipes and C. intermedius

342 are potential hosts of Korean $S$. confragosa and $P$. yatsui because of the limited pool of crab host

343 species examined in this study. Extensive taxon sampling of decapod hosts and their parasitic

344 barnacles is needed to obtain a complete understanding of the host ranges of rhizocephalan

345 barnacles and the distribution and prevalence of host-parasite associations.

346 The decapod host infestation rate of Korean rhizocephalan barnacles was much lower than that

347 reported for Japanese species. In Japan, 35 individuals representing three rhizocephalan species

348 were found in 354 individuals of three crab species, corresponding to an infestation rate of $9.9 \%$

349 (Tsuchida et al., 2006). By contrast, the infestation rate of Korean rhizocephalans was substantially

350 lower at $1.2 \%$ on average (Table 1). Species richness and extent of host usage by parasitic

351 barnacles are tightly correlated to the availability of host species (species diversity and abundance;

352 Kamiya et al., 2014). Differences in the extent of host usage by rhizocephalan barnacles between

353 the two geographic regions are likely due to differences in host species diversity and abundance,

354 as well as the sample size of examined materials (e.g., total numbers of individuals and host

355 species). Since we examined the prevalence of rhizocephalans on all decapod hosts (a total of

3563,262 host individuals inspected), our result is likely an accurate estimate of the infestation rate.

357 On the other hand, this prevalence difference between Korea and Japan may be originated from

358 salinity, season, host sex and size (Mouritsen et al., 2018) or biogeographical differences (Kim et 
359 al., 2020). In a previous study, the infestation rate of Korean hermit crabs by rhizocephalans was

360 reported to be $0.9 \%$ (Jung et al. 2019), which is similar to the infestation rate observed in this

361 study. The unexpectedly high infestation rates (> 50\%) of Pachygrapsus crassipes and Arcotheres

362 sinensis are due to strong bias from the very small sample size (one to four individuals) examined.

363 Extensive sampling of parasitic barnacles from a wide range of decapod host species is necessary

364 to better understand their prevalence, infection intensity, and host range specificity.

365 In addition to their host ranges, morphological and molecular analyses in this study provided 366 insights into the taxonomy of Korean rhizocephalan barnacle species. In Korea, the presence of 367 four rhizocephalan families, i.e., Polyascidae, Sacculinidae, Peltogastridae, and Peltogasterellidae 368 are reported by this study and previous studies (Jung et al., 2019; Høeg et al., 2019). Polyascidae 369 is characterized by multiple externa and can reproductive by asexual reproduction (Glenner et al. 370 2003), Sacculinidae is characterized by single externa and sexual reproduction. Peltogastridae and

371 Peltogasterellidae are mainly parasite on hermit crabs, and Peltogastridae is distinguished from

372 Peltogasterellidae by the presence of the chitinous shield on its middle part of externae (Høeg et 373 al., 2019). Phylogenetic trees in this study proved that morphological classifications of these 374 rhizocephalan families are corresponding with molecular results, as shown in Høeg et al. (2019).

375 Two new species candidates in the genus Parasacculina (Parasacculina sp. 1 and Parasacculina 376 sp. 2) were recognized based on molecular phylogenetic analyses. These species were distinct from 377 their congeneric species, $P$. leptodiae and $P$. sinensis, based on phylogenetic analyses of mtDNA 378 (16S rDNA) and nuclear (18S rDNA) sequences (Fig. 3B-3C) even though they are 379 morphologically indistinguishable and were found in the same host species. These two species are 380 genetically distinct cryptic species. Furthermore, we transferred three Korean Sacculina species 381 (i.e. Sacculina imberbis, S. pilosella, and S. pinnotherae) to the genus Parasacculina because they 
382 grouped with Parasacculina species in mtDNA cox1, 16S, and 18S rDNA phylogenetic trees (Fig.

383 3A-3C). This new taxonomic replacement is consistent with previous studies that transferred 384 several Japanese and Chinese Sacculina species to Parasacculina based on molecular evidence 385 (Tsuchida et al., 2006; Glenner et al., 2010; Høeg et al., 2019).

386

Comparison of the external cuticles of Korean species with previously published morphological data provided new insight into the taxonomic status of the families Sacculinidae and Polyascidae. Although Høeg et al. (2019) showed that Sacculinidae and Polyascidae are phylogenetically distinct, the original descriptions of Polyascidae (Høeg et al., 2019) did not specify morphological characters differentiating this family from Sacculinidae. For example, Høeg et al. (2019) noted that polyascids have a smooth or almost smooth external cuticle, but some polyascid species $(P$. pinnotherae comb. nov. and P. yatsui) in the present study had wrinkled cuticles (Fig. 2C, 2F). In addition, Høeg et al. (2019) mentioned that Polyascus species have multiple externae, but Polyascus cf. gregarius in this study had only a single externa (Fig. 2G). Numerous cases have been reported that morphological characters of male host crabs become feminized due to the presence of parasitic barnacles (Kobayashi et al., 2018; Høeg et al., 2019; Korn et al., 2020), and there are also numerous previous studies in which various parasites undergo different development stage with differentiated morphological characters such as Hematodinium spp. and Plasmodium spp. (Stentiford \& Shields, 2005; Howick et al., 2019). However, the variation in the number of externa of $P$. cf. gregarius in this study is a very rare case in which specific parasite exhibits a morphological variation depending on the host within the same development stage. These results indicate that the morphological characteristics of external cuticles, previously considered to be taxonomically valid features, are highly variable and cannot be used as diagnostic characters. Future comparative analyses of morphological characters along with molecular sequences are 
405 necessary to confirm the taxonomic status of Sacculinidae and Polyascidae and the taxonomic 406 replacement of the three Korean Sacculina species in the genus Parasacculina.

407

\section{Conclusions}

409 In conclusion, this is the first report of the taxonomy, species diversity, and host ranges of Korean 410 parasitic rhizocephalan barnacles based on morphological and molecular analyses. We identified 411 nine parasitic barnacle species, including two new species candidates in the genus Parasacculina, 412 in Korea. In addition, we found higher host specificity and lower infestation rates for Korean 413 rhizocephalan species than reported for rhizocephalan species from other geographic regions. 414 Nevertheless, the results of this study are based on preliminary data derived from limited taxon 415 sampling in a narrow geographic range in Korea. Additional data from extensive samplings of 416 parasitic barnacles from a wide range of crustacean host species are necessary to better understand 417 the taxonomy, prevalence, host usage, and phylogenetic relationships of rhizocephalan species.

\section{Competing interests}

420 The authors declare that they have no conflict of interest.

\section{Authors Contributions}

423 Jibom Jung contributed to the study design, field works, acquisition, data analysis, interpretation 424 of the sequence data, and drafting the manuscript.

425 Ryuta Yoshida contributed to the field works. 
426 Damin Lee contributed to the field works.

427 Joong-ki Park contributed to the study design, acquisition, data analysis, interpretation of the 428 sequence data, and drafting the manuscript.

430 Funding

431 This work was supported by a grant from the National Institute of Biological Resources (NIBR), 432 funded by the Ministry of Environment (MOE) of the Republic of Korea (NIBR202102203; 433 NIBR202102108), a grant from the Hallyeohaesang National Park survey project supported by the 434 Korea National Park Service. The present study was partly supported by a Showa Seitoku 435 Memorial Foundation.

\section{Acknowledgements}

438

439

440

441

442

443

444

445

446

Jongwoo Jung, Hee-seung Hwang (Ewha Womans University), Hyun Kyong Kim (Honam National Institute of Biological Resources), Jin-Hyeop Jeong (Soonchunhyang University), and Heesoo Kim (Korea Polar Research Institute) helped sample the materials analyzed in this study. Sang-Hui Lee helped identification of $P$. intermedia, the host of $P$. pilosella. We thank Iriomote Station, Tropical Biosphere Research Center, University of the Ryukyus and Marine and Coastal Research Center, Ochanomizu University for providing laboratory facilities, and Mr. Yuki Miyaoka and his friends for generous help in sampling.

\section{References}


447 Boschma H. 1933. The Rhizocephala in the collection of the British Museum. Journal of the $448 \quad$ Linnean Society of London 38:473-552, 1 pl

449

450

451

452

453

454

455

456

457

458

459

460

461

462

463

464

465

466

467

468

469

Boschma H. 1936. The specific characters of Sacculina rotundata Miers and Sacculina yatsui nov. spec. Zoologische Mededelingen 19:1-22

Boschma H. 1955. Rhizocephalan parasites of the crab Pugettia brevirostris, with notes on Sacculina gracilis. Zoologische Mededelingen 33:237-249

Chan BKK, Dreyer N, Gale AS, Glenner H, Ewers-Saucedo C, Pérez-Losada M, Kolbasov GA, Crandall KA, Høeg JT. 2021. The evolutionary diversity of barnacles, with an updated classification of fossil and living forms. Zoological Journal of the Linnean Society zlaa 160

Folmer O, Black M, Hoeh W, Lutz R, Vrijenhoek R. 1994. DNA primers for amplification of mitochondrial cytochrome c oxidase subunit I from diverse metazoan invertebrates. Molecular Marine Biology and Biotechnology 3(5):294-299

Glenner H, Høeg JT, Stenderup J, Rybakov AV. 2010. The monophyletic origin of a remarkable sexual system in akentrogonid rhizocephalan parasites is confirmed by molecular and larval structural data. Experimental Parasitology 125:3-12

Glenner H, Lützen J, Takahashi T. 2003. Molecular and morphological evidence for a monophyletic clade of asexually reproducing Rhizocephala: Polyascus, new genus (Cirripedia). Journal of Crustacean Biology 23:548-557

Guérin-Ganivet J. 1911. Contribution a l'étude systématique et biologique des rhizocéphales. Travaux Scientifique du Laboratoire de Zoologie et de Physiologie Maritimes de Concarneau 3:1-97, pl. 1

Heng-Xiang Li, Li-Sha Ma, Xiu-Juan Yu, Lu Li, Chang-Ping Yang, Yan Yan. 2015. Colonization of Octolasmis (Cirripedia) on the Crab Portunus Sanguinolentus (Brachyura: 
Portunidae): Impacts of the Parasitism of Diplothylacus sinensis (Cirripedia: Rhizocephala).

Høeg JT. 1992. Rhizocephala. In FW Harrison, AG Humes, eds. Microscopic anatomy of invertebrates, Vol. 9, Crustacea. New York: Wiley, pp. 313-345

Høeg JT, Lützen J. 1985. Crustacea Rhizocephala. Marine invertebrates of Scandinavia 6. Oslo: Norwegian Univ Press

Høeg, JT, Lützen J. 1995. Life cycle and reproduction in the Cirripedia Rhizocephala. Oceanography and Marine Biology: An Annual Review 33:427-485

Høeg JT, Noever C, Rees DA, Crandall KA, Glenner H. 2019. A new molecular phylogenybased taxonomy of parasitic barnacles (Crustacea: Cirripedia: Rhizocephala). Zoological Journal of the Linnean Society 190(2):632-653

Howick VM, Russell AJ, Andrews T, Heaton H, Reid AJ, Natarajan K, ... Lawniczak MK, 2019. The Malaria Cell Atlas: Single parasite transcriptomes across the complete Plasmodium life cycle. Science, 365(6455)

Jung J, Yoshida R, Kim W. 2019. Diversity of Parasitic Peltogastrid Barnacles (Crustacea: Cirripedia: Rhizocephala) on Hermit Crabs in Korea. Zoological Studies 58:33

Kamiya T, O’Dwyer K, Nakagawa S, Poulin R. 2014. Host diversity drives parasite diversity: meta-analytical insights into patterns and causal mechanisms. Ecography 37:689-697

Kearse M, Moir R, Wilson A, Stones-Havas S, Cheung M, Sturrock S et al., 2012. Geneious Basic: an integrated and extendable desktop software platform for the organization and analyses of sequence data. Bioinformatics 28:1647-1649

Kim HK, Chan BKK, Lee S-K, Kim W. 2020. Biogeography of intertidal and subtidal native 492 and invasive barnacles in Korea in relation to oceanographic current ecoregions and global 
493

494

495

496

497

498

499

500

501

502

503

504

505

506

507

508

509

510

511

512

513

514

515

climatic changes. Journal of the Marine Biological Association of the United Kingdom 100: 1079-1091

Kimura M. 1980. A simple method for estimating evolutionary rates of base substitutions through comparative studies of nucleotide sequences. Journal of Molecular Evolution 16(2):111-120

Kobayashi M, Wong YH, Oguro-Okano M, Dreyer N, Høeg JT, Yoshida R, Okano K. 2018. Identification, characterization, and larval biology of a rhizocephalan barnacle, Sacculina yatsui Boschma, 1936, from northwestern Japan (Cirripedia: Sacculinidae). Journal of Crustacean Biology 38(3):329-340(2)

Korn OM, Golubinskaya DD, Rees DJ, Glenner H, Høeg JT. 2020. Phylogenetic position, complete larval development and larval sexual dimorphism in a rhizocephalan barnacle, Lernaeodiscus rybakovi sp. nov.(Cirripedia: Rhizocephala: Peltogastridae), parasitizing the crab Pachycheles stevensii Stimpson, 1858 (Decapoda: Anomura: Porcellanidae). Zoologischer Anzeiger 287:178-197

Krüger P. 1912. Über ostasiatische Rhizocephalen. Anhang: Über einige Vertreter der Cirripedia Thoracica. Abhandlungen der Mathematisch-Physikalischen Klasse der Königlich Bayerischen Akademie der Wissenschaften 2:1-8

Kumar S, Stecher G, Li M, Knyaz C, Tamura K. 2018. MEGA X: molecular evolutionary genetics analysis across computing platforms. Molecular Biology and Evolution 35(6):15471549

Lilljeborg W. 1861. Supplément au mémoire sur les genres Liriope et Peltogaster, H. Rathke. Nova acta Regiae Societatis Scientiarum Upsaliensis 3:74-102, pl. 6

Lützen J, Itani G, Jespersen Å, Hong JS, Rees D, Glenner H. 2016. On a new species of parasitic barnacle (Crustacea: Rhizocephala), Sacculina shiinoi sp. nov., parasitizing 
516

517

518

519

520

521

522

523

524

525

526

527

528

529

530

531

532

533

534

535

536

537

538

Japanese mud shrimps Upogebia spp.(Decapoda: Thalassinidea: Upogebiidae), including a description of a novel morphological structure in the Rhizocephala. Zoological Science 33(2):204-212

McDermott JJ. 2009. Hypersymbioses in the pinnotherid crabs (Decapoda: Brachyura: Pinnotheridae): a review. Journal of Natural History 43(13-14):785-805

Mouritsen K, Geyti S, Lützen J, Høeg JT, Glenner H. 2018. Population dynamics and development of the rhizocephalan, Sacculina carcini, parasitic on the shore crab Carcinus maenas. Diseases of Aquatic Organisms 131:199-211

Nagasawa K, Lützen J, Kado R. 1996. Parasitic Cirripedia (Rhizocephala) and Isopoda from brachyuran and anomuran crabs of the Pacific coast of northern Honshu, Japan. Bulletin of the Biogeographical Society of Japan 51:1-6

Noever C, Olson A, Glenner H. 2016. Two new cryptic and sympatric species of the king crab parasite Briarosaccus (Cirripedia: Rhizocephala) in the North Pacific. Zoological Journal of the Linnean Society 176(1):3-14

Okada YK, Miyashita Y. 1935. Sacculinization in Eriocheir japonicus de Haan, with remarks on the occurrence of complete sex-reversal in parasitized male crabs. Memoirs of the College of Science, Kyoto Imperial University. Ser. B 10(3):169-208

Øksnebjerg B. 2000. The Rhizocephala (Crustacea: Cirripedia) of the Mediterranean and Black Seas: taxonomy, biogeography, and ecology. Israel Journal of Zoology 46:1-102(2)

Reinhard EG. 1942. Studies on the life history and host-parasite relationship of Peltogaster paguri. Biology Bulletin 83(3):401-415

Ronquist F, Huelsenbeck J, Teslenko M. 2011. MrBayes version 3.2 manual: tutorials and model summaries. mrbayessourceforgenet/mb32_manualpdf 
539 Schubart CD, Neigel JE, Felder DL. 2000. Use of the mitochondrial 16S rRNA gene for

540 phylogenetic and population studies of Crustacea. Crustacean Issues 12(1):817-830

541 Shiino SM. 1943. Rhizocephala of Japan. Journal of Sigenkagaku Kenkyusyo 1:1-36

542 Spears T, Abele LG, Kim W, 1992. The monophyly of brachyuran crabs: a phylogenetic study 543 based on 18S rRNA. Systematic Biology 41(4):446e461

544 Stamatakis A, 2014. RAxML version 8: a tool for phylogenetic analysis and post-analysis of large 545 phylogenies. Bioinformatics, 30(9):1312-1313

546 Stentiford GD, Shields JD, 2005. A review of the parasitic dinoflagellates Hematodinium species 547 and Hematodinium-like infections in marine crustaceans. Diseases of aquatic organisms, $548 \quad 66(1): 47-70$

549 Tamura K, Nei M. 1993. Estimation of the number of nucleotide substitutions in the control 550 region of mitochondrial DNA in humans and chimpanzees. Molecular Biology and Evolution 10(3):512-526

Tavaré S. 1986. Some probabilistic and statistical problems in the analysis of DNA sequences. Lectures on mathematics in the life sciences 17(2):57-86

554

555

Thompson JV. 1836. Natural history and metamorphosis of an anomalous crustaceous parasite of Carcinus maenas, the Sacculina carcini. The Entomologist's monthly magazine 3:452-456

Tsuchida K, Lützen J, Nishida M. 2006. Sympatric three-species infection by Sacculina parasites (Cirripedia: Rhizocephala: Sacculinidae) of an intertidal grapsoid crab. Journal of Crustacean Biology 26(4):474-479

Tu TH, Chan BK, Jeng MS. 2009. Larval development and sex ratio variation of Polyascus plana (Cirripedia: Rhizocephala), a parasite of the crab Grapsus albolineatus, in Taiwan. Bulletin of Marine Science 84(3):331-349 
562 Utinomi H, Kikuchi T. 1966. Fauna and flora of the sea around the Amakusa Marine Biological

563 Laboratory, Part VI, Cirriped Crustacea. Amakusa Marine Biological Laboratory 195:1-11

564 (in Japanese)

565 Van Kampen PN, Boschma H. 1925. Die Rhizocephala der Siboga-Expedition. Siboga566 Expeditie. 31bis:1-62, pls. 1-3

567 Yoshida R, Hirose M, Mok HK, Hirose E. 2012. The first records of peltogastrid rhizocephalans

568 (Crustacea: Cirripedia: Rhizocephala) on hermit crabs (Paguroidea) in Taiwan and 569 differences in prevalences among collection sites. Zoological Studies 51(7):1027-1039

570 Yoshida R, Hirose M, Hirose E. 2014. Hermit crab host prevalence by species of Peltogastridae 571 (Cirripedia: Rhizocephala): hosts vary with locations on the Pacific coast in mainland Japan. $572 \quad$ Journal of Crustacean Biology 34(4):467-480

573 Yoshida R, Osawa M, Hirose M, Hirose E. 2011. A new genus and two new species of 574 Peltogastridae (Crustacea: Cirripedia: Rhizocephala) parasitizing hermit crabs from 575 Okinawa Island (Ryukyu Archipelago, Japan), and their DNA-barcodes. Zoological Science $576 \quad 28: 853-862$.

577 
578

579

580

581

582

583

584

585

586

587

588

589

590

591

592

593

594

595

596

597

598

599

\section{Figure legends}

Figure 1. Map showing the collection sites of the Korean rhizocephalan species. Symbols indicate the presence of parasitic barnacles at collection sites, nine Korean rhizocephalans in this study are blue colored and eight rhizocephalans in Jung et al. (2019) are black. 1, Sacculina confragosa; 2, Parasacculina imberbis; 3, Parasacculina pilosella; 4, Parasacculina pinnotherae; 5, Parasacculina shiinoi; 6, Parasacculina sp. 1; 7, Parasacculina sp. 2; 8, Parasacculina yatsui; 9, Polyascus cf. gregarius; 10, Peltogaster lineata; 11, Peltogaster postica; 12, Peltogaster aff. ovalis; 13, Peltogaster aff. reticulatus; 14, Peltogaster sp. 1; 15, Peltogaster sp. 2; 16, Peltogaster sp. 3; 17, Peltogasterella gracilis.

Figure 2. Externae of Korean rhizocephalans. Red arrow: mantle, scale bar: 2 mm. A, Sacculina confragosa; B, Parasacculina pilosella comb. nov.; C, Parasacculina pinnotherae comb. nov.; D, Parasacculina sp. 1; E, Parasacculina sp. 2; F, Parasacculina yatsui; G, Polyascus cf. gregarius. Externae of some specimens (B, D-G) were incomplete, in case they were used for molecular analysis (B, D-G).

Figure 3. Phylogenetic relationships among Korean rhizocephalan species. Maximum likelihood and Bayesian inference methods were used to analyze mtDNA coxl (A), 16S (B), and nuclear 18S rRNA (C) sequence data. Values on nodes indicate maximum likelihood bootstrap support/Bayesian posterior probability. Sequences from Korean species determined in this study are indicated in blue. *: sequences derived from GenBank, **: Japanese sequences obtained in this study. 
601 Figure 4. The vertical bar chart showing the individual number of each Korean rhizocephalan 602 species found in each host. 


\section{Figure 1}

Map showing the collection sites of the Korean rhizocephalan species.

Numbered circles indicate sampling localities where rhizocephalan species were sampled in this study (blue) and Jung et al. (2019; black). 1, Sacculina confragosa; 2, Parasacculina imberbis; 3, Parasacculina pilosella; 4, Parasacculina pinnotherae; 5, Parasacculina shiinoi; 6 , Parasacculina sp. 1; 7, Parasacculina sp. 2; 8, Parasacculina yatsui; 9, Polyascus cf. gregarius; 10, Peltogaster lineata; 11, Peltogaster postica; 12, Peltogaster aff. ovalis; 13, Peltogaster aff. reticulatus; 14, Peltogaster sp. 1; 15, Peltogaster sp. 2; 16, Peltogaster sp. 3; 17, Peltogasterella gracilis. 


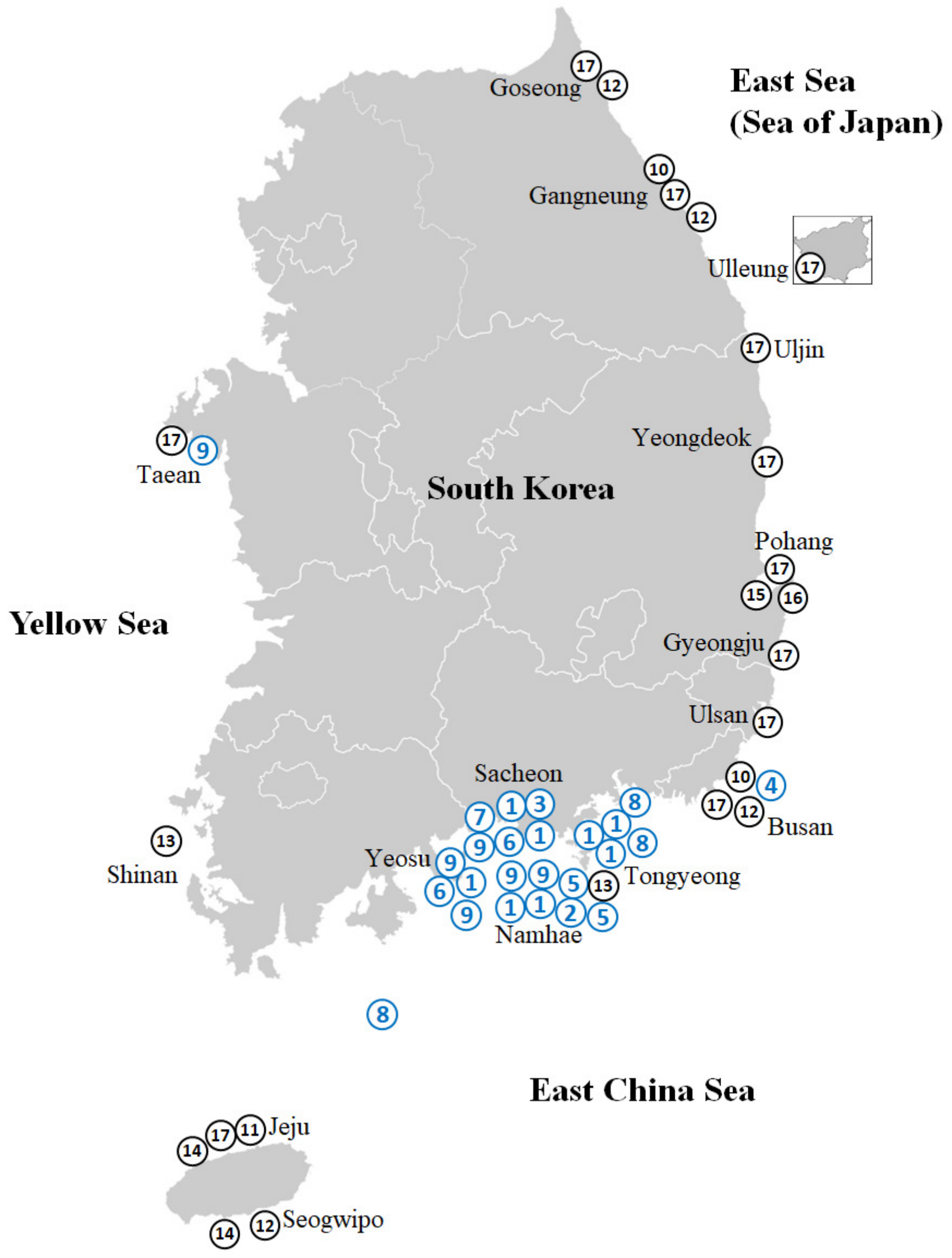




\section{Figure 2}

Externae of Korean rhizocephalans.

Red arrow: mantle, scale bar: $2 \mathrm{~mm}$. (A) Sacculina confragosa. (B) Parasacculina pilosella comb. nov.. (C) Parasacculina pinnotherae comb. nov.. (D) Parasacculina sp. 1. (E) Parasacculina sp. 2. (F) Parasacculina yatsui. (G) Polyascus cf. gregarius. Externae of some specimens (B, D-G) were incomplete, in case they were used for molecular analysis (B, D-G). 

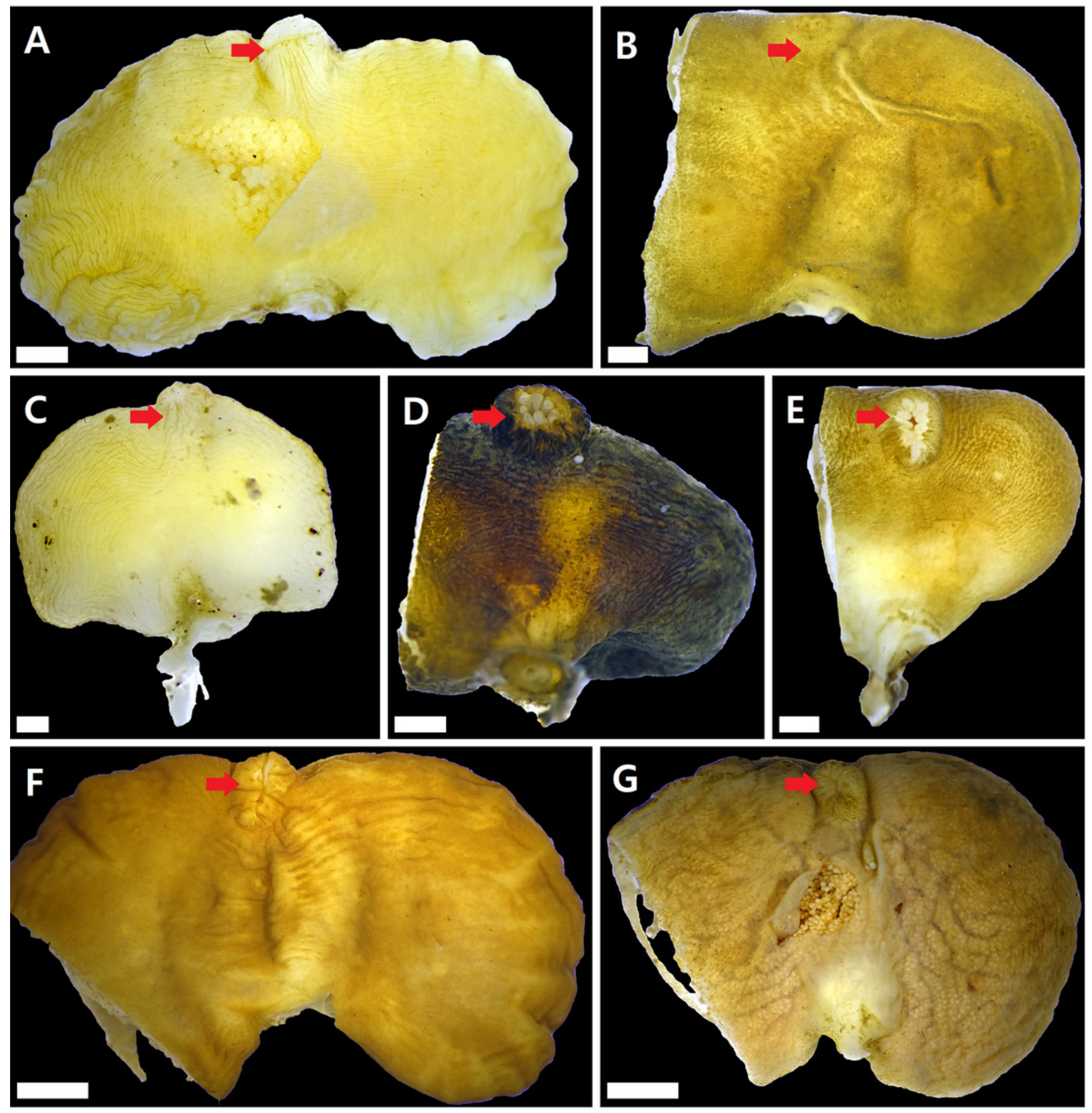
Figure 3

Phylogenetic relationships among Korean rhizocephalan species.

Maximum likelihood and Bayesian inference methods were used to analyze mtDNA cox1 (A), 16S (B), and nuclear 18S rRNA (C) sequence data. Values on nodes indicate maximum likelihood bootstrap support/Bayesian posterior probability. Sequences from Korean species determined in this study are indicated in blue. *: sequences derived from GenBank, **: Japanese sequences obtained in this study.
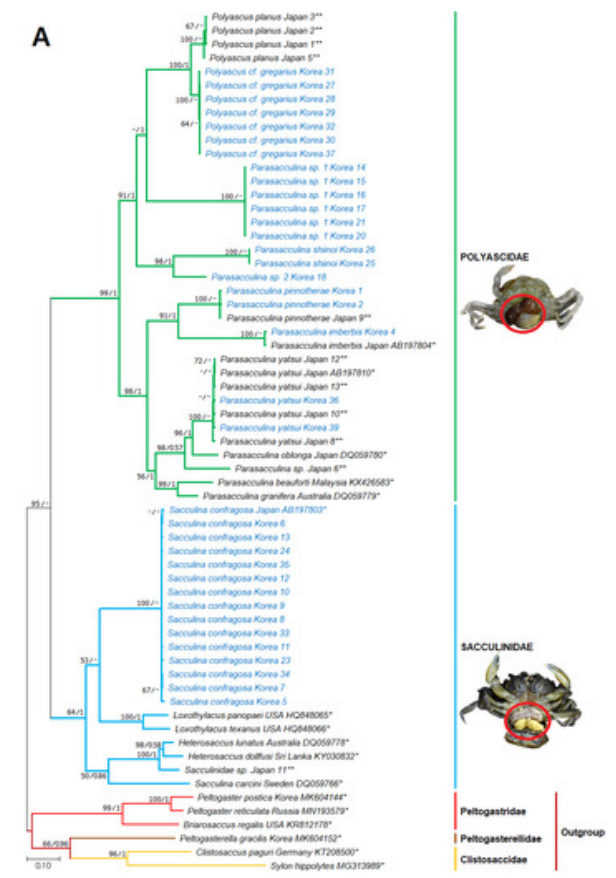

B

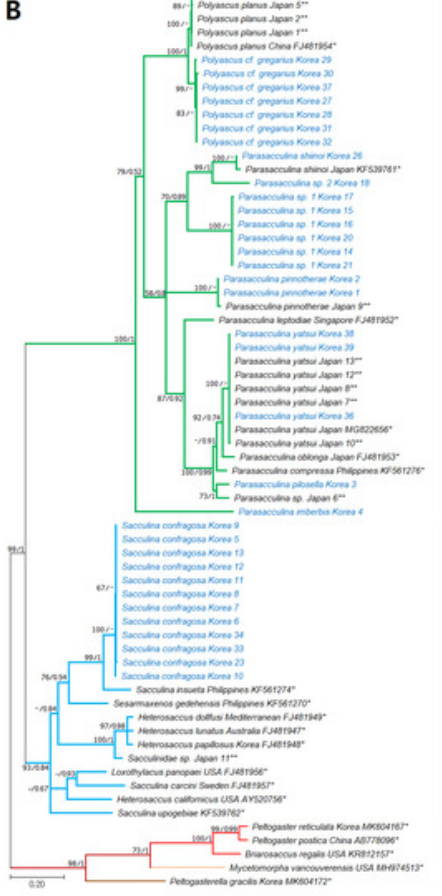

C

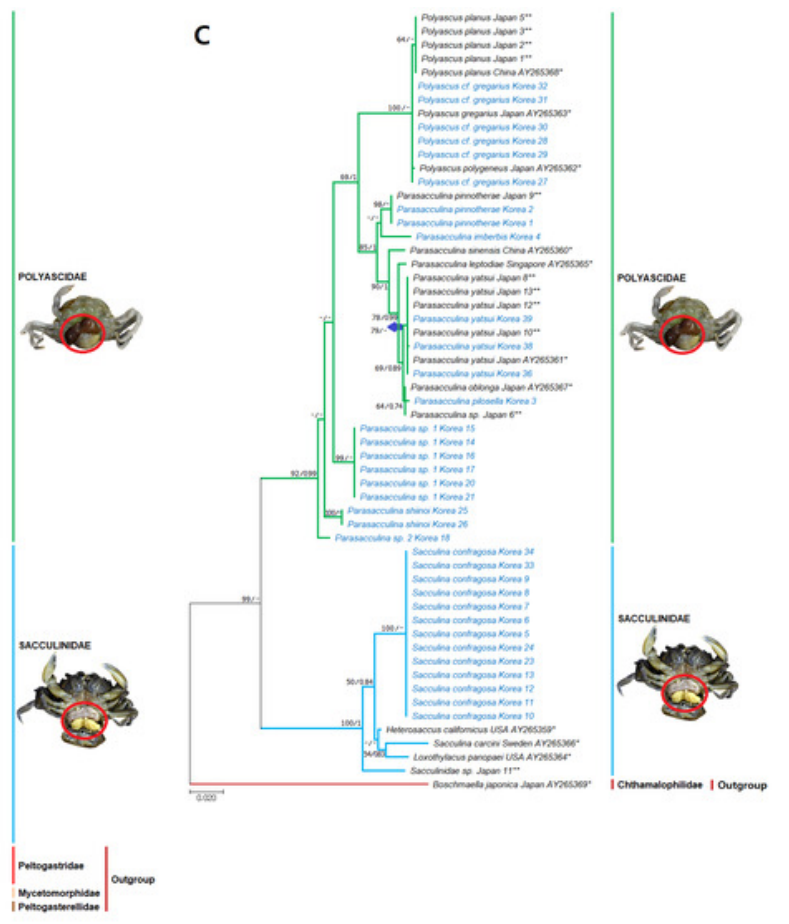


Figure 4

A vertical bar chart showing the individual number of nine Korean rhizocephalan species found from their hosts.

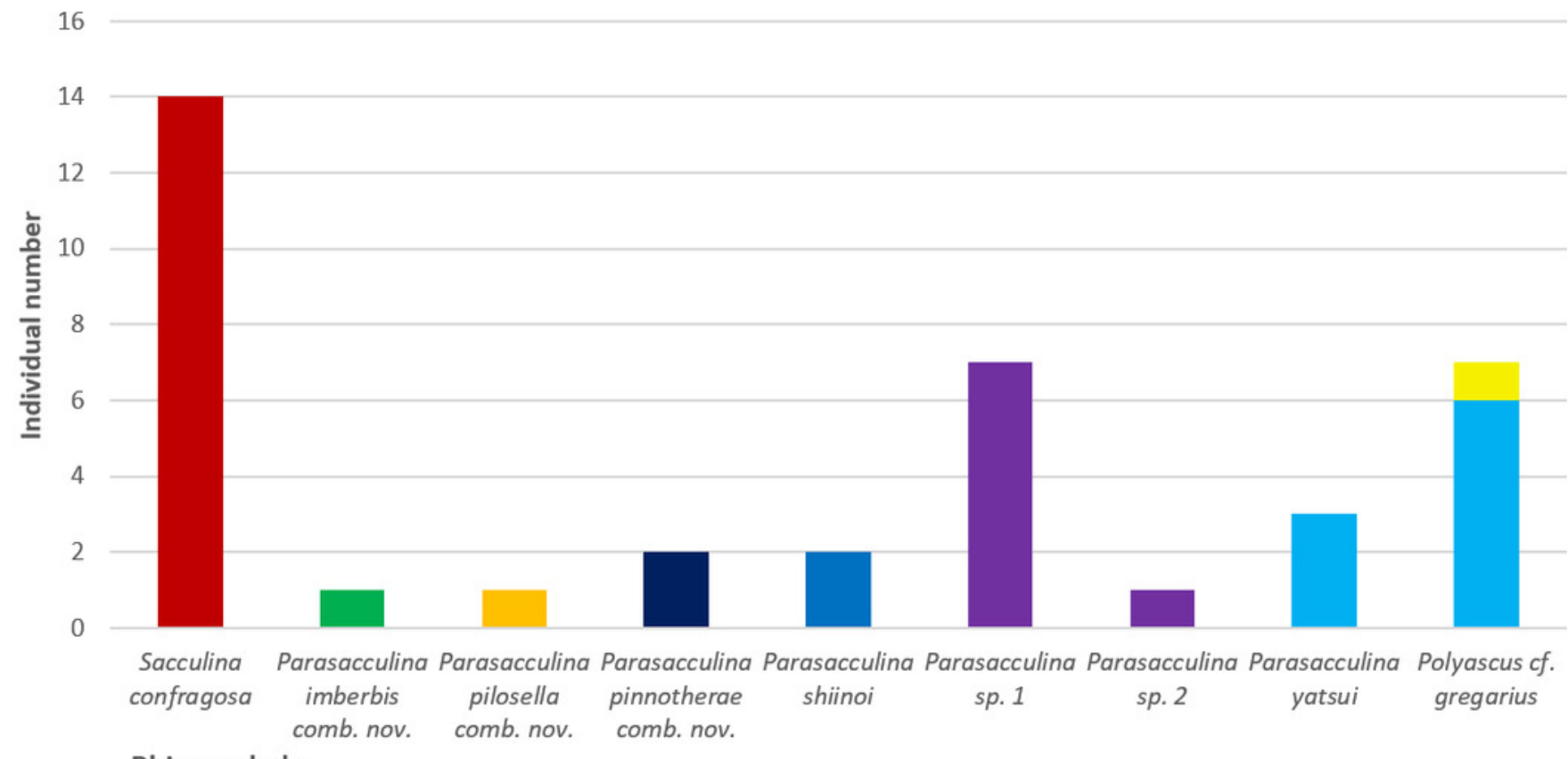

Rhizocephala

\begin{tabular}{|lll|}
\hline - Gaetice depressus & - Pachygrapsus crassipes & Mugettia intermedia \\
- Arcotheres sinensis & - Upogebia major & Macromedaeus distinguendus \\
m Hemigrapsus sanguineus & Hemigrapsus takanoi & Host \\
\hline
\end{tabular}




\section{Table 1 (on next page)}

Individual number and infestation rate (\%) of Korean decapod species by rhizocephalan parasitic barnacles examined in this study. 
1 Table 1: Individual number and infestation rate (\%) of Korean decapod species by 2 rhizocephalan parasitic barnacles examined in this study.

\begin{tabular}{|c|c|c|c|}
\hline Host decapod species & $\begin{array}{l}\text { Total number of } \\
\text { individuals examined }\end{array}$ & $\begin{array}{l}\text { Number of } \\
\text { individuals infested }\end{array}$ & $\begin{array}{l}\text { Infestation } \\
\text { rate }\end{array}$ \\
\hline Alpheus bisincisus & 16 & 0 & $0.0 \%$ \\
\hline Arcotheres sinensis & 4 & 2 & $50.0 \%$ \\
\hline Eualus sinensis & 16 & 0 & $0.0 \%$ \\
\hline Gaetice depressus & 1400 & 14 & $1.0 \%$ \\
\hline Helicana japonica & 28 & 0 & $0.0 \%$ \\
\hline Hemigrapsus penicillatus & 50 & 0 & $0.0 \%$ \\
\hline Hemigrapsus sanguineus & 114 & 9 & $7.9 \%$ \\
\hline Hemigrapsus takanoi & 145 & 1 & $0.7 \%$ \\
\hline Ilyoplax dentimerosa & 10 & 0 & $0.0 \%$ \\
\hline Ilyoplax pusilla & 57 & 0 & $0.0 \%$ \\
\hline Laomedia astacina & 15 & 0 & $0.0 \%$ \\
\hline Macromedaeus distinguendus & 74 & 8 & $10.8 \%$ \\
\hline $\begin{array}{l}\text { Macrophthalmus (Mareotis) } \\
\text { japonicus }\end{array}$ & 45 & 0 & $0.0 \%$ \\
\hline Neotrypaea japonica & 35 & 0 & $0.0 \%$ \\
\hline Pachygrapsus crassipes & 1 & 1 & $100.0 \%$ \\
\hline Pagurus lanuginosus & 65 & 0 & $0.0 \%$ \\
\hline Pagurus minutus & 811 & 0 & $0.0 \%$ \\
\hline Pagurus nigrofascia & 28 & 0 & $0.0 \%$ \\
\hline Palaemon serrifer & 17 & 0 & $0.0 \%$ \\
\hline Parasesarma pictum & 61 & 0 & $0.0 \%$ \\
\hline Pugettia intermedia & 14 & 1 & $7.1 \%$ \\
\hline Scopimera globosa & 25 & 0 & $0.0 \%$ \\
\hline Sestrostoma balssi & 16 & 0 & $0.0 \%$ \\
\hline Stenalpheops anacanthus & 61 & 0 & $0.0 \%$ \\
\hline Upogebia major & 154 & 2 & $1.3 \%$ \\
\hline Total & 3262 & 38 & $1.2 \%$ \\
\hline
\end{tabular}




\section{Table 2 (on next page)}

GenBank accession numbers, geographic information, and host species of rhizocephalan species used for phylogenetic analysis in this study.

*: sequences derived from GenBank. 
1 Table 2: GenBank accession numbers, geographic information, and host species of 2 rhizocephalan species used for phylogenetic analysis in this study. *: sequences derived from 3 GenBank.

\begin{tabular}{|c|c|c|c|c|c|c|}
\hline Species & Host species & Location & $\begin{array}{l}\text { Specimen } \\
\text { number }\end{array}$ & $\begin{array}{l}\text { coxl } \\
\text { GenBank } \\
\text { accession } \\
\text { no }\end{array}$ & $\begin{array}{l}\text { 16S rDNA } \\
\text { GenBank } \\
\text { accession } \\
\text { no }\end{array}$ & $\begin{array}{l}\text { 18S rDNA } \\
\text { GenBank } \\
\text { accession } \\
\text { no }\end{array}$ \\
\hline $\begin{array}{l}\text { Boschmaella } \\
\text { japonica* }\end{array}$ & $\begin{array}{l}\text { Chthamalus } \\
\text { challengeri }\end{array}$ & $\begin{array}{l}\text { Jôgashima, } \\
\text { Japan }\end{array}$ & $\begin{array}{l}\text { ZMUC } \\
\text { CRU-3877 }\end{array}$ & & & AY265369 \\
\hline $\begin{array}{l}\text { Briarosaccus } \\
\text { regalis* }\end{array}$ & $\begin{array}{l}\text { Paralithodes } \\
\text { camtschaticus }\end{array}$ & Alaska, USA & & KR812178 & KR812157 & \\
\hline $\begin{array}{l}\text { Clistosaccus } \\
\text { paguri* }\end{array}$ & & Germany & & KT208500 & & \\
\hline Heterosaccus & Loxorhynchus & CA, USA & & & AY520756 & \\
\hline californicus* & grandis & $\begin{array}{l}\text { Santa Barbara, } \\
\text { USA }\end{array}$ & $\begin{array}{l}\text { ZMUC } \\
\text { CRU-3875 }\end{array}$ & & & AY265359 \\
\hline $\begin{array}{l}\text { Heterosaccus } \\
\text { dollfusi } *\end{array}$ & $\begin{array}{l}\text { Charybdis } \\
\text { longicollis }\end{array}$ & Mediterranean & & & FJ481949 & \\
\hline & $\begin{array}{l}\text { Portunus } \\
\text { pelagicus }\end{array}$ & Sri Lanka & & KY030832 & & \\
\hline $\begin{array}{l}\text { Heterosaccus } \\
\text { lunatus* }\end{array}$ & $\begin{array}{l}\text { Charybdis } \\
\text { callianassa }\end{array}$ & $\begin{array}{l}\text { Moreton Bay, } \\
\text { Australia }\end{array}$ & & DQ059778 & FJ481947 & \\
\hline $\begin{array}{l}\text { Heterosaccus } \\
\text { papillosus* }\end{array}$ & $\begin{array}{l}\text { Charybdis } \\
\text { bimaculata }\end{array}$ & Korea & & & FJ481948 & \\
\hline $\begin{array}{l}\text { Loxothylacus } \\
\text { panopaei* }\end{array}$ & $\begin{array}{l}\text { Rhithropanope } \\
\text { us harrisii }\end{array}$ & $\begin{array}{l}\text { Neuse River, } \\
\text { USA }\end{array}$ & $\begin{array}{l}\text { ZMUC } \\
\text { CRU-3876 }\end{array}$ & & FJ481956 & AY265364 \\
\hline & xanthoid crabs & USA & & HQ848065 & & \\
\hline $\begin{array}{l}\text { Loxothylacus } \\
\text { texanus* }\end{array}$ & xanthoid crabs & USA & & HQ848066 & & \\
\hline $\begin{array}{l}\text { Mycetomorpha } \\
\text { vancouverensis } \\
*\end{array}$ & & Alaska, USA & & & MH974513 & \\
\hline $\begin{array}{l}\text { Parasacculina } \\
\text { beauforti* }\end{array}$ & Scylla olivacea & Malaysia & & KX426583 & & \\
\hline $\begin{array}{l}\text { Parasacculina } \\
\text { compressa* }\end{array}$ & $\begin{array}{l}\text { Ozius } \\
\text { tuberculosus }\end{array}$ & $\begin{array}{l}\text { Panglao, } \\
\text { Philippines }\end{array}$ & & & KF561276 & \\
\hline
\end{tabular}




\begin{tabular}{|c|c|c|c|c|c|c|}
\hline $\begin{array}{l}\text { Parasacculina } \\
\text { granifera* }^{*}\end{array}$ & $\begin{array}{l}\text { Portunus } \\
\text { pelagicus }\end{array}$ & $\begin{array}{l}\text { Moreton Bay, } \\
\text { Australia }\end{array}$ & & DQ059779 & & \\
\hline Parasacculina & Pachygrapsus & Namhae, Korea & Korea 4 & MZ216470 & MZ215675 & MZ215557 \\
\hline $\begin{array}{l}\text { imberbis comb. } \\
\text { nov. }\end{array}$ & crassipes & $\begin{array}{l}\text { Shirosaki, } \\
\text { Japan* }\end{array}$ & S2 & AB197804 & & \\
\hline Parasacculina & Leptodius & Labrador, & ZMUC & & FJ481952 & AY265365 \\
\hline leptodiae* & affinis & Singapore & CRU-3870 & & & \\
\hline Parasacculina & Cyclograpsus & Amakusa, Japan & G4028 & DQ059780 & & \\
\hline oblonga* & intermedius & Tomioka, Japan & ZMUC & & FJ481953 & AY265367 \\
\hline & & & CRU-3871 & & & \\
\hline Parasacculina & Pugettia & Sacheon, Korea & VSJAIV00 & & MZ215679 & MZ215561 \\
\hline pilosella comb. & intermedia & & 00000010 & & & \\
\hline nov. & & & (Korea 3) & & & \\
\hline Parasacculina & Arcotheres & Imabari, Japan & CMNH- & MZ216499 & MZ215676 & MZ215558 \\
\hline pinnotherae & sinensis & & ZC-02762 & & & \\
\hline comb. nov. & & & (Japan 9) & & & \\
\hline & & Busan, Korea & Korea 1 & MZ216468 & MZ215677 & MZ215559 \\
\hline & & & Korea 2 & MZ216469 & MZ215678 & MZ215560 \\
\hline Parasacculina & Leptodius & Hong Kong, & ZMUC & & & AY265360 \\
\hline sinensis* & affinis & China & CRU-3874 & & & \\
\hline Parasacculina & Upogebia & Namhae, Korea & Korea 25 & MZ216486 & & MZ215562 \\
\hline shiinoi & major & & Korea 26 & MZ216487 & MZ215680 & MZ215563 \\
\hline & & Japan* & & & KF539761 & \\
\hline Parasacculina & Macromedaeus & Sacheon, Korea & Korea 15 & MZ216480 & MZ215683 & MZ215566 \\
\hline sp. 1 & distinguendus & & Korea 16 & MZ216481 & MZ215684 & MZ215567 \\
\hline & & & Korea 17 & MZ216482 & MZ215685 & MZ215568 \\
\hline & & & Korea 20 & MZ216511 & MZ215686 & MZ215569 \\
\hline & & & Korea 21 & MZ216484 & MZ215687 & MZ215570 \\
\hline & & Yeosu, Korea & Korea 14 & MZ216479 & MZ215682 & MZ215565 \\
\hline & & & Korea 19 & & & \\
\hline Parasacculina & Macromedaeus & Sacheon, Korea & Korea 18 & MZ216483 & MZ215688 & MZ215571 \\
\hline sp. 2 & distinguendus & & & & & \\
\hline Parasacculina & Guinusia & Tateyama, Japan & CMNH- & MZ216497 & MZ215681 & MZ215564 \\
\hline sp. & dentipes & & ZC-02756 & & & \\
\hline & & & (Japan 6) & & & \\
\hline Parasacculina & Hemigrapsus & Taean, Korea & VSJAIV00 & MZ216507 & MZ215694 & MZ215576 \\
\hline yatsui & sanguineus & & 00000011 & & & \\
\hline
\end{tabular}




\begin{tabular}{|c|c|c|c|c|c|c|}
\hline & & & (Korea 36) & & & \\
\hline & & Toga Bay, & & & MG822656 & \\
\hline & & Japan* & & & & \\
\hline & & Tongyeong, & Korea 38 & & MZ215695 & MZ215577 \\
\hline & & Korea & Korea 39 & MZ216509 & MZ215696 & MZ215578 \\
\hline & $\begin{array}{l}\text { Pachygrapsus } \\
\text { crassipes }\end{array}$ & Misaki, Japan & $\begin{array}{l}\text { CMNH- } \\
\text { ZC-02770 } \\
\text { (Japan13) }\end{array}$ & MZ216503 & MZ215691 & MZ215574 \\
\hline & & Tateyama, Japan & $\begin{array}{l}\text { CMNH- } \\
\text { ZC-02764 } \\
\text { (Japan10) }\end{array}$ & MZ216500 & MZ215689 & MZ215572 \\
\hline & & Katsuura, Japan & $\begin{array}{l}\text { CMNH- } \\
\text { ZC-02758 } \\
\text { (Japan 7) }\end{array}$ & & MZ215692 & \\
\hline & & Tateyama, Japan & $\begin{array}{l}\text { CMNH- } \\
\text { ZC-02760 } \\
\text { (Japan 8) }\end{array}$ & MZ216498 & MZ215693 & MZ215575 \\
\hline & & $\begin{array}{l}\text { Shirosaki, } \\
\text { Japan* }\end{array}$ & S13 & AB197810 & & \\
\hline & & Tateyama, Japan & $\begin{array}{l}\text { CMNH- } \\
\text { ZC-02768 } \\
\text { (Japan 12) }\end{array}$ & MZ216502 & MZ215690 & MZ215573 \\
\hline $\begin{array}{l}\text { Peltogasterella } \\
\text { gracilis* }\end{array}$ & Pagurus filholi & Gyeongju, Korea & $\begin{array}{l}\text { MADBK } \\
160707 \_03 \\
9\end{array}$ & MK604152 & & \\
\hline & $\begin{array}{l}\text { Pagurus } \\
\text { pectinatus }\end{array}$ & Busan, Korea & $\begin{array}{l}\text { MADBK } \\
430103 \_00 \\
2\end{array}$ & & MK604172 & \\
\hline $\begin{array}{l}\text { Peltogaster } \\
\text { postica* }\end{array}$ & $\begin{array}{l}\text { Pagurus } \\
\text { angustus }\end{array}$ & Chisi, Taiwan & $\begin{array}{l}\text { NMNS- } \\
6795-003\end{array}$ & & AB778096 & \\
\hline & Pagurus filholi & Jeju, Korea & $\begin{array}{l}\text { MADBK } \\
430102 \_00 \\
2\end{array}$ & MK604144 & & \\
\hline $\begin{array}{l}\text { Peltogaster } \\
\text { reticulata* }\end{array}$ & $\begin{array}{l}\text { Pagurus } \\
\text { minutus }\end{array}$ & Namhae, Korea & $\begin{array}{l}\text { MADBK } \\
160706 \_06 \\
5\end{array}$ & & MK604167 & \\
\hline & & Vostok Bay, & & MN193579 & & \\
\hline
\end{tabular}




\begin{tabular}{|c|c|c|c|c|c|c|}
\hline \multirow{3}{*}{$\begin{array}{l}\text { Polyascus } \\
\text { gregarius* }\end{array}$} & \multirow{3}{*}{$\begin{array}{l}\text { Eriocheir } \\
\text { japonica }\end{array}$} & \multicolumn{5}{|l|}{ Russia } \\
\hline & & Maruyama, & ZMUC & & & AY265363 \\
\hline & & Japan & CRU-3869 & & & \\
\hline \multirow{14}{*}{$\begin{array}{l}\text { Polyascus cf. } \\
\text { gregarius }\end{array}$} & \multirow{12}{*}{$\begin{array}{l}\text { Hemigrapsus } \\
\text { sanguineus }\end{array}$} & \multirow[t]{4}{*}{ Namhae, Korea } & VSJAIV00 & MZ216488 & MZ215697 & MZ215579 \\
\hline & & & 00000013 & & & \\
\hline & & & (Korea 27) & & & \\
\hline & & & Korea 30 & MZ216513 & MZ215700 & MZ215582 \\
\hline & & Sacheon, Korea & Korea 29 & MZ216490 & MZ215699 & MZ215581 \\
\hline & & \multirow[t]{3}{*}{ Taean, Korea } & VSJAIV00 & MZ216508 & MZ215703 & \\
\hline & & & 00000012 & & & \\
\hline & & & (Korea 37) & & & \\
\hline & & \multirow[t]{4}{*}{ Yeosu, Korea } & VSJAIV00 & MZ216489 & MZ215698 & MZ215580 \\
\hline & & & 00000014 & & & \\
\hline & & & (Korea 28) & & & \\
\hline & & & Korea 31 & MZ216491 & MZ215701 & MZ215583 \\
\hline & Hemigrapsus & Namhae, Korea & Korea 32 & MZ216492 & MZ215702 & MZ215584 \\
\hline & takanoi & & & & & \\
\hline \multirow{14}{*}{$\begin{array}{l}\text { Polyascus } \\
\text { planus }\end{array}$} & \multirow{5}{*}{$\begin{array}{l}\text { Grapsus } \\
\text { albolineatus }\end{array}$} & Nakagusuku, & RUMF- & MZ216494 & MZ215705 & MZ215586 \\
\hline & & Okinawa, Japan & ZC-7303 & & & \\
\hline & & & (Japan 2) & & & \\
\hline & & Kenting, & ZMUC & & FJ481954 & AY265368 \\
\hline & & Taiwan* & CRU-3872 & & & \\
\hline & \multirow{9}{*}{$\begin{array}{l}\text { Metopograpsus } \\
\text { messor }\end{array}$} & Nago, Okinawa, & RUMF- & MZ216495 & MZ215706 & MZ215587 \\
\hline & & Japan & ZC-7305 & & & \\
\hline & & & (Japan 3) & & & \\
\hline & & Iriomote, Japan & RUMF- & MZ216496 & MZ215707 & MZ215588 \\
\hline & & & ZC-7309 & & & \\
\hline & & & (Japan 5) & & & \\
\hline & & Nago, Okinawa, & RUMF- & MZ216493 & MZ215704 & MZ215585 \\
\hline & & Japan & ZC-7301 & & & \\
\hline & & & (Japan 1) & & & \\
\hline \multirow{2}{*}{$\begin{array}{l}\text { Polyascus } \\
\text { polygeneus* }\end{array}$} & Hemigrapsus & \multirow[t]{2}{*}{ Ôyano, Japan } & ZMUC & & & AY265362 \\
\hline & sanguineus & & CRU-3873 & & & \\
\hline Sacculina & Carcinus & Gullmar Fjord, & ZMUC & & FJ481957 & AY265366 \\
\hline $\operatorname{carcini}^{*}$ & maenas & Sweden & CRU-3867 & & & \\
\hline \multirow{2}{*}{$\begin{array}{l}\text { Sacculina } \\
\text { confragosa }\end{array}$} & Gaetice & Namhae, Korea & Korea 11 & MZ216477 & MZ215709 & MZ215590 \\
\hline & \multicolumn{2}{|l|}{ depressus } & VSJAIV00 & MZ216478 & MZ215710 & MZ215591 \\
\hline
\end{tabular}




\begin{tabular}{|c|c|c|c|c|c|}
\hline & & $\begin{array}{l}00000015 \\
\text { (Korea 12) }\end{array}$ & & & \\
\hline & Sacheon, Korea & Korea 5 & MZ216471 & MZ215715 & MZ215597 \\
\hline & & Korea 6 & MZ216472 & MZ215716 & MZ215598 \\
\hline & & Korea 7 & MZ216473 & MZ215717 & MZ215599 \\
\hline & & Korea 8 & MZ216474 & MZ215718 & MZ215600 \\
\hline & & Korea 9 & MZ216475 & MZ215719 & MZ215601 \\
\hline & & Korea 10 & MZ216476 & MZ215708 & MZ215589 \\
\hline & & Korea 23 & MZ216485 & MZ215712 & MZ215593 \\
\hline & & Korea 24 & MZ216512 & & MZ215594 \\
\hline & Tongyeong, & VSJAIV00 & MZ216504 & MZ215713 & MZ215595 \\
\hline & Korea & 00000016 & & & \\
\hline & & (Korea 33) & & & \\
\hline & & Korea 34 & MZ216505 & MZ215714 & MZ215596 \\
\hline & & Korea 35 & MZ216506 & & \\
\hline & Yeosu, Korea & Korea 13 & MZ216510 & MZ215711 & MZ215592 \\
\hline Pachygrapsus & Shirama, Japan & ZMUC & & & AY265361 \\
\hline crassipes* & & CRU-3868 & & & \\
\hline & Shirosaki, Japan & S22 & AB197803 & & \\
\hline Ptychognathus & Kawasan, & & & KF561274 & \\
\hline riedelii & Philippines & & & & \\
\hline & & & & KF539762 & \\
\hline Thalamita sp. & Tateyama, Japan & CMNH- & MZ216501 & MZ215720 & MZ215602 \\
\hline & & ZC-02766 & & & \\
\hline & & (Japan 11) & & & \\
\hline Sesarmops sp. & Kawasan, & & & KF561270 & \\
\hline & Philippines & & & & \\
\hline & & & MG313989 & & \\
\hline
\end{tabular}




\section{Table 3(on next page)}

Morphological features of the externa of nine Korean rhizocephalans. 
1 Table 3: Morphological features of the externa of nine Korean rhizocephalans.

\begin{tabular}{|c|c|c|c|c|}
\hline \multirow[t]{2}{*}{ Species } & \multirow{2}{*}{$\begin{array}{l}\text { Externa } \\
\text { Shape }\end{array}$} & \multicolumn{3}{|c|}{ Mantle aperture } \\
\hline & & $\begin{array}{l}\text { Externa } \\
\text { number }\end{array}$ & Projection & Opening \\
\hline Sacculina confragosa & Wrinkled flat cordiform & $\begin{array}{l}\text { Single or } \\
\text { double }\end{array}$ & Elevated tube & Circular \\
\hline $\begin{array}{l}\text { Parasacculina imberbis } \\
\text { comb. nov. }\end{array}$ & Smooth round-rectangular & Single & & \\
\hline $\begin{array}{l}\text { Parasacculina pilosella } \\
\text { comb. nov. }\end{array}$ & Smooth and slightly flat oval & Single & Flat & Circular \\
\hline $\begin{array}{l}\text { Parasacculina } \\
\text { pinnotherae comb. nov. }\end{array}$ & $\begin{array}{l}\text { Smooth or slightly wrinkled } \\
\text { flat oval or cordiform }\end{array}$ & $\begin{array}{l}\text { Single or } \\
\text { double }\end{array}$ & Elevated & Dot shaped \\
\hline Parasacculina shiinoi & Smooth oval & Single & & \\
\hline Parasacculina sp. 1 & $\begin{array}{l}\text { Smooth or slightly wrinkled } \\
\text { oval }\end{array}$ & Single & Elevated & Circular \\
\hline Parasacculina sp. 2 & Smooth oval & Single & Slightly elevated & Circular \\
\hline Parasacculina yatsui & $\begin{array}{l}\text { Smooth or slightly wrinkled } \\
\text { flat oval or flat cordiform }\end{array}$ & Single & Elevated & Slit shaped \\
\hline Polyascus cf. gregarius & $\begin{array}{l}\text { Smooth or slightly wrinkled } \\
\text { flat cordiform }\end{array}$ & Single & Elevated & Slit shaped \\
\hline
\end{tabular}

